CLINICAL STUDY

\title{
Familial growth hormone deficiency with mutated GHRH receptor gene: clinical and hormonal findings in homozygous and heterozygous individuals from Itabaianinha
}

César Y Hayashida, Rogério G Gondo, Carmela Ferrari, Sérgio P A Toledo, Roberto Salvatori ${ }^{1}$, Michael A Levine ${ }^{1,2}$, Marilza C L Ezabella, Neusa Abelin, Daniel Gianella-Neto ${ }^{3}$ and Bernardo L Wajchenberg ${ }^{3}$

Endocrine-Genetics Unit/LIM 25, Endocrine Division, Department of Medicine, São Paulo University School of Medicine, O1246-903, São Paulo, Brazil, ${ }^{1}$ Division of Endocrinology, Department of Medicine, and ${ }^{2}$ Department of Pediatrics, The Johns Hopkins University School of Medicine, Baltimore Maryland, USA, and ${ }^{3}$ Diabetes and Adrenal Unit, Endocrine Division, Department of Medicine, São Paulo University School of Medicine, São Paulo, Brazil.

(Correspondence should be addressed to César Y Hayashida, Faculdade de Medicina da Universidade de São Paulo, Unidade de Endocrinologia Genétical LIM 25, Av. Dr. Arnaldo, 455, 5ªndar, 01246-903 São Paulo, Brazil; Email: hayashidacesar@hotmail.com)

\begin{abstract}
Objective: To characterize clinically and hormonally the syndrome of autosomal recessive familial growth hormone deficiency (FGHD) recently identified in Itabaianinha, Sergipe, Brazil, caused by a novel mutation (mt) that inactivates the growth hormone-releasing hormone receptor (GHRH-R) gene. Design: Clinical and hormonal evaluations were performed in 21 FGHD individuals ( $\mathrm{mt} / \mathrm{mt}$ group) aged 8 to 63 years, 13 heterozygotes for the GHRH-R mutation (wt/mt group) and 5 homozygotes for the wild type (wt) allele (wt/wt group), identified by genotyping of peripheral blood leukocyte DNA. Methods: Clinical and hormonal characterization included physical examination and measurement of GH, IGF-I, IGF binding protein-3 (IGFBP-3), cortisol, prolactin, LH, FSH, and free thyroxine (FT4). Results: Clinical features were consistent with isolated growth hormone deficiency. Height was significantly reduced in the $\mathrm{mt} / \mathrm{mt}$ group compared with the $\mathrm{wt} / \mathrm{mt}$ group (mean height standard deviation score (SDS) \pm S.D.: $-7.35 \pm 1.37$ vs $-1.84 \pm 1.44$ respectively, $P<0.0001$ ), and the wt/wt group $(-1.85 \pm 0.81, P=0.0007)$. The height of the $13 \mathrm{wt} / \mathrm{mt}$ subjects did not differ from the $5 \mathrm{wt} / \mathrm{wt}$ individuals. Serum GH, IGF-I, IGF-I SDS, IGFBP-3 and IGFBP-3 SDS were all significantly lower in the $\mathrm{mt} / \mathrm{mt}$ group than in the $\mathrm{wt} / \mathrm{mt}$ and $\mathrm{wt} / \mathrm{wt}$ groups. Two affected children treated with $\mathrm{GH}$ for 1 year showed a normal growth response. Serum IGF-I and IGF-I SDS were lower in wt/mt compared with wt/wt group, but did not reach statistical significance. IGF-I and IGF-I SDS correlated inversely with age in $\mathrm{wt} / \mathrm{mt}$ group.

Conclusions: FGHD due to an autosomal recessive GHRH-R gene mutation leads to marked dwarfism, phenotypically and hormonally indistinguishable from other forms of isolated GH deficiency. Heterozygotes for the GHRH-R mutation appear to have a partial defect in the GH/IGF axis, with no apparent height impairment.
\end{abstract}

European Journal of Endocrinology 142 557-563

\section{Introduction}

In 1994, newspaper reports first described the existence of a large number of very short individuals ('dwarves') in Itabaianinha. Itabaianinha is a rural area located in the northeastern Brazilian state of Sergipe, $118 \mathrm{~km}$ southwest from the state capital, Aracaju. Approximately 32000 people live in Itabaianinha, of whom 13000 reside in the urban area, the city of Itabaianinha, with the remaining population spread over a very poorly developed rural area. In 1995, a clinical and genetic study of some families with affected individuals was started that led to the recent identification of a novel homozygous donor splice site mutation $(\mathrm{mt})$ ( $\mathrm{G}$ to
A at position +1$)$ in intron 1 of the growth hormone releasing hormone (GHRH) receptor (GHRH-R) gene as the cause of familial growth hormone deficiency (FGHD) in this population (1). This report details clinical and biochemical characteristics of subjects who are homozygous (mt/mt) or heterozygous (wt/mt) for the GHRH$\mathrm{R}$ gene mutation (wt, wild-type GHRH-R allele).

\section{Subjects and methods}

\section{Subjects}

Affected subjects and normal controls from the same families were selected on the basis of height. Written 
informed consent was obtained from all subjects. A limited physical examination, including height, was performed, and peripheral venous blood was collected for hormonal measurements and DNA extraction. All affected individuals and the respective families appear caucasian, and some had blond hair. Twenty-one short individuals from 12 families, and 18 unaffected family members were evaluated (Table 1). Standard deviation scores (SDS) of height were calculated based on growth charts published by the World Health Organisation (2). Body mass index (BMI) of 10 affected $(\mathrm{mt} / \mathrm{mt})$ and 3 heterozygous (wt/mt) subjects was calculated as weight $(\mathrm{kg}) /$ height $(\mathrm{m})^{2}$. BMI percentile for height age (BMI\%ile for HA) was calculated based on a published chart (3).

Among the 18 family members with normal stature who served as the control group, 13 were determined to be heterozygous (wt/mt) and 5 to be homozygous for the wild type allele (wt/wt) for GHRH-R gene, via genotyping by denaturing gradient gel electrophoresis (1). Therefore, the control group was divided into two subgroups, wt/mt and wt/wt (Table 1). All the phenotypically affected subjects were confirmed to be homozygous for the mutation.

\section{Hormone measurements}

Serum was separated from blood after one hour standing at room temperature, and frozen at $-20{ }^{\circ} \mathrm{C}$ until assay a few days later. Growth hormone $(\mathrm{GH})$ was measured by IRMA (CIS, Gif-Sur-Yvette Cedex, France). Insulin-like growth factor-I (IGF-I) was measured by RIA after acid-ethanol extraction (Nichols Institute, San Juan Capistrano, CA, USA), and insulin-like growth factor-binding protein-3 (IGFBP-3) was measured by IRMA (Active IGFBP-3, DSL 6600, Diagnostic Systems Laboratory, Webster, TX, USA). Serum thyroxine (T4) (RIA) and thyrotrophin (TSH) (IRMA) were measured using commercial kits from DPC, Los Angeles, CA, USA. Prolactin (PRL), cortisol, luteinizing hormone (LH), and follicle-stimulating hormone (FSH), measured by fluoroimmunoassay (Auto Delfia, Wallac, Turku, Finland) were also determined for the same sera.

\section{Treatment}

Patients 1 and 3 were treated with daily subcutaneous applications of human recombinant GH (Genotropin, Pharmacia and Upjohn, Sao Paulo, Brazil), $0.1 \mathrm{U} / \mathrm{kg}$ body weight/day, for one year.

\section{Statistical analysis}

Serum concentrations of IGF-I and IGFBP-3 for each individual were expressed as standard deviation scores (SDS) from the mean to conform to age and sex differences in normal values provided by the manufacturers of the IGF-I and IGFBP-3 kits. The Mann-Whitney rank sum test was used to compare height, SDS of height, serum concentrations of GH, IGF-I SDS and IGFBP-3 SDS between affected $(\mathrm{mt} / \mathrm{mt})$ individuals, heterozygous (wt/mt) and homozygous (wt/wt) normal subjects. Spearman rank order tests were used to evaluate correlations between age, height, SDS of height, serum GH, IGF-I SDS and IGFBP-3 SDS.

\section{Results}

Clinical data and serum hormone levels are presented in Table 1. One of the pedigrees indicates a high degree of consanguinity (Fig. 1). Among the 12 nuclear families studied, approximately $40 \%$ of the siblings of each proband were affected, ranging from 11\% (family of patient 14 ) to $100 \%$ (family of patient 9 ). There were equal numbers of females $(n=11)$ and males $(n=10)$. None of the parents were affected in this sample. These observations are consistent with autosomal recessive inheritance of $\mathrm{GH}$ deficiency (GHD) and a founder effect (1).

Affected individuals had proportionate short stature, with excessive trunkal fat and poorly developed muscle mass. Normal secondary sex characteristics were present after puberty, which appeared to occur at the normal age. Children and adults had high pitched voices. Small developmental defects such as ear deformities were noted in some of the affected subjects.

All affected individuals were very short. The SDS from the mean height for the 21 affected individuals taken together was $-7.35 \pm 1.37$ (mean \pm s.D.) (range: -9.98 to -4.54$)$ compared with wt/mt $(-1.84 \pm 1.44$, range: -4.45 to $\left.1.29, Z_{T}=4.84, \quad P<0.0001\right)$ and $w t / w t$ $\left(-1.85 \pm 0.81\right.$, range: -2.61 to $-0.61, Z_{T}=3.43$, $P=0.0007)$, with highly significant statistical differences. Mean height SDS for those $\mathrm{mt} / \mathrm{mt}$ individuals less than 18 years of age was $-6.24 \pm 0.84$ (range: -6.82 to $-4.54, n=7$ ) compared with $-0.41 \pm 1.54$ (range: -1.70 to $1.29, n=3$ ) for combined (due to the low number of individuals) $\mathrm{wt} / \mathrm{mt}$ and $\mathrm{wt} / \mathrm{wt}$ individuals $(P<0.06)$. Affected adult male height $(18$ years and older) was $123.3 \pm 7.62 \mathrm{~cm}$ (range: 111 to $135 \mathrm{~cm}$, $n=9$ ) compared with $163.0 \pm 4.53 \mathrm{~cm}$ (range: 159 to $170 \mathrm{~cm}, n=5$ ) for their combined adult male $\mathrm{wt} / \mathrm{mt}$ and wt/wt relatives $\left(Z_{T}=3.023, P=0.003\right)$. Affected adult females measured $118.8 \pm 8.53 \mathrm{~cm}$ (range: 105 to $125 \mathrm{~cm}, n=5$ ) compared with $150.8 \pm 7.31 \mathrm{~cm}$ (range: 137 to $162 \mathrm{~cm}, n=10$ ), for their combined adult female $w t / \mathrm{mt}$ and $w t / w t$ relatives $\left(Z_{T}=3.003, P=0.003\right)$.

$\mathrm{BMI} \%$ ile for HA was 25 for case 1 . All other 9 affected individuals in which this parameter could be determined were at the 75 th or above percentile (Table 1 ). $\mathrm{BMI} \%$ iles for $\mathrm{HA}$ in $3 \mathrm{wt} / \mathrm{mt}$ relatives were considered normal (percentiles 50 to 90).

Mean \pm S.D. random serum GH (Fig. 2A) was: (i) for the affected (mt/mt) group: $0.102 \pm 0.063 \mathrm{ng} / \mathrm{ml}$ (range: 0.006 to $0.211 \mathrm{ng} / \mathrm{ml}$ ); (ii) for the $\mathrm{wt} / \mathrm{mt}$ group: $0.377 \pm 0.324 \mathrm{ng} / \mathrm{ml}$ (range: 0.026 to $1.062 \mathrm{ng} / \mathrm{ml}$ ) 
Table 1 Short stature from Itabaianinha: data from GH deficient subjects and their relatives.

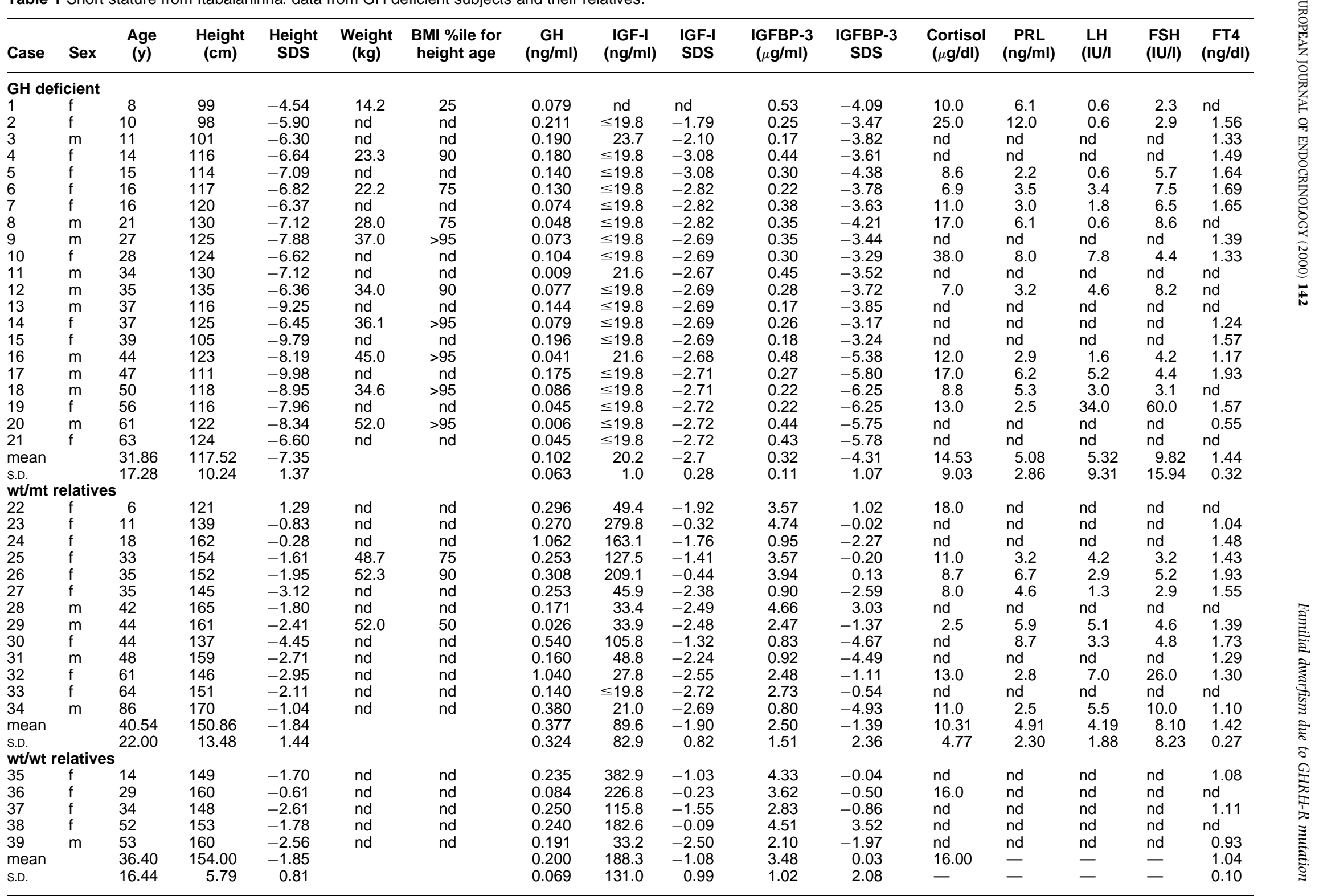

通. Normal values for GH: 0-7 ng/ml; IGF-I (ng/ml), 6-8 y: 88-474; 9-11 y: 117-771 (fem), 110-565 (male): 12-15 y: $261-1096$ (fem), $202-957$ (male); 16-24 y: 182-780; 25-39 y: 114-492; 40-54 y: 90-360; 55+ y: 71-290; IGFBP-3 ( $\mu \mathrm{g} / \mathrm{ml}$ ), 0-6 y: 1.03-4.25; 7-39 y: 1.25-7.33 (male), 1.8-8.41 (fem); 39+y: 2.02-7.26; FT4: 0.8-2 $\mu \mathrm{U} / \mathrm{ml}$; nd: not determined. 


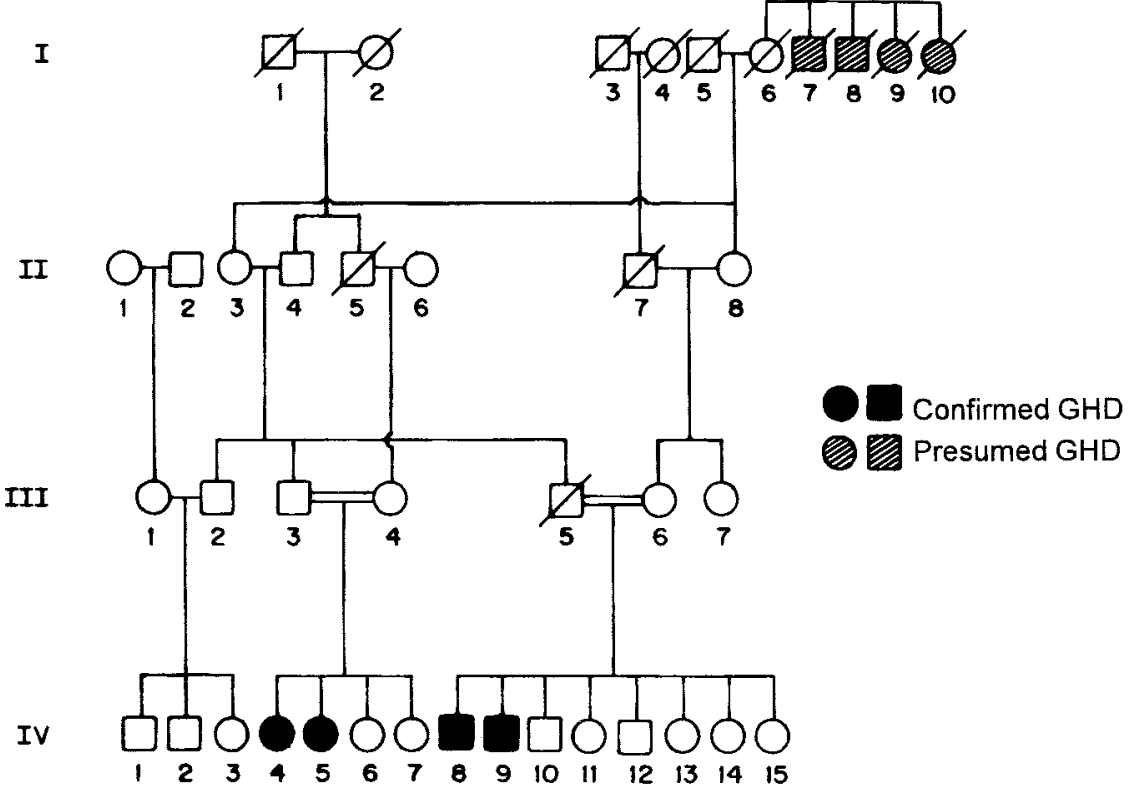

Figure 1 Genealogy from families of patients 5 and 7 (IV-4 and IV-5 respectively), and 8 (IV-8), showing multiple consanguineous marriages and autosomal recessive pattern of inheritance. Squares, male; circles, female.

$\left(Z_{T}=3.58, P=0.0004\right)$; and (iii) for the wt/wt group: $0.200 \pm 0.069 \mathrm{ng} / \mathrm{ml}$ (range: 0.084 to $0.250 \mathrm{ng} / \mathrm{ml}$ ) $\left(Z_{T}=2.65, P=0.009\right.$, relative to $\left.\mathrm{mt} / \mathrm{mt}\right)$.

Serum GH was less than $0.1 \mathrm{ng} / \mathrm{ml}$ in $12 / 21$ affected individuals, and in only one wt/mt (no. 29) and one wt/ wt (no. 36) individual. Four wt/mt (nos 28, 29, 31, and 33) and two wt/wt (nos 36 and 39) individuals had serum GH levels that overlapped with the affected group (Table 1). There was an inverse correlation between serum GH and age in the affected group $\left(r_{s}=-0.47\right.$, $P=0.03)$, but not in the wt/mt group $\left(r_{s}=-0.16\right.$, $P=0.61)$ or in the wt/wt group $\left(r_{s}=0.10, P=0.95\right)$.

Serum IGF-I was undetectable $(\leq 19.8 \mathrm{ng} / \mathrm{ml})$ in 17 of 20 affected individuals (serum IGF-I was not measured in individual no. 1), and very low in the remaining $3(21.6$ to $23.7 \mathrm{ng} / \mathrm{ml})$, with a mean value (assuming $19.8 \mathrm{ng} / \mathrm{ml}$ for those with $\leq 19.8 \mathrm{ng} / \mathrm{ml}$ ) of $20.2 \pm 1.0 \mathrm{ng} / \mathrm{ml}$ (range: $\leq 19.8$ to $23.7 \mathrm{ng} / \mathrm{ml}$ ). By contrast, values in normal stature $\mathrm{wt} / \mathrm{mt}$ subjects were $89.6 \pm 82.9 \mathrm{ng} / \mathrm{ml}$ (range: $\leq 19.8$ to $279.8 \mathrm{ng} / \mathrm{ml}$ ) $\left(\mathrm{Z}_{T}=4.52, P<0.0001\right)$, and in wt/wt subjects they were $188.3 \pm 131.0 \mathrm{ng} / \mathrm{ml}$ (range: 33.2 to $382.9 \mathrm{ng} / \mathrm{ml}$ ) $\left(Z_{T}=3.76, P=0.0008\right.$ relative to $\left.\mathrm{mt} / \mathrm{mt}\right)$. Serum IGF-I of the three oldest control individuals, all $\mathrm{wt} / \mathrm{mt}(61,64$, and 86 years of age: $27.8 \mathrm{ng} / \mathrm{ml}, \leq 19.8 \mathrm{ng} / \mathrm{ml}$, and $21 \mathrm{ng} / \mathrm{ml}$ respectively) overlapped with values observed in the GHD group. Serum IGF-I, expressed as SDS, was $2.68 \pm 0.28$, range: -3.08 to -1.79 for the $\mathrm{mt} / \mathrm{mt}$ group, $-1.90 \pm 0.81$, range: -2.72 to -0.32 for the $\mathrm{wt} / \mathrm{mt}$ group $\left(\mathrm{Z}_{T}=3.63, \mathrm{P}=0.0003\right)$, and $-1.08 \pm$ 0.99 , range: -2.50 to -0.09 for the $w t / w t$ group $\left(\mathrm{Z}_{T}=3.25, P=0.001\right.$, relative to $\mathrm{mt} / \mathrm{mt}$ group) (Fig. $\left.2 \mathrm{~B}\right)$.
Serum IGFBP-3 was significantly lower in the affected group: $0.32 \pm 0.11 \mu \mathrm{g} / \mathrm{ml}$ (range: 0.17 to $0.53 \mu \mathrm{g} / \mathrm{ml}$ ), compared with the wt/mt group: $2.50 \pm 1.51 \mu \mathrm{g} / \mathrm{ml}$ (range: 0.80 to $4.74 \mu \mathrm{g} / \mathrm{ml}),\left(Z_{T}=4.85, P<0.0001\right.$ ), and the $w \mathrm{t} / \mathrm{wt}$ group: $3.48 \pm 1.02 \mu \mathrm{g} / \mathrm{ml}$ (range: 2.10 to $4.51 \mu \mathrm{g} / \mathrm{ml}),\left(Z_{T}=3.43, P=0.0007\right)$. IGFBP-3 in the $\mathrm{wt} / \mathrm{mt}$ group tended to decrease with increasing age, without reaching statistical significance $\left(r_{s}=-0.51\right.$, $P=0.07$ ), and was below the normal range in five individuals (nos 24, 27, 30, 31, and 34). Serum IGFBP3 , expressed as SDS, was $-4.31 \pm 1.07$, range: -6.25 to -3.17 for the $\mathrm{mt} / \mathrm{mt}$ group, $-1.39 \pm 2.36$, range: -4.93 to 3.03 for the $\mathrm{wt} / \mathrm{mt}$ group $\left(Z_{T}=3.25\right.$, $P=0.001$ ), and $0.03 \pm 2.08$, range: -1.97 to 3.52 for the wt/wt group $\left(Z_{T}=3.43, P=0.0007\right.$, relative to $\mathrm{mt} / \mathrm{mt}$ group) (Fig. 2C). There was an inverse correlation between age of affected individuals and IGFBP-3 SDS $\left(r_{s}=-0.45, P=0.04\right)$. IGFBP-3 SDS tended to decrease with age in wt/mt individuals, without reaching statistical significance $\left(r_{s}=-0.53, P=0.06\right)$.

Serum random cortisol, PRL, LH, FSH, and free T4 (FT4) were normal, except in subject no. 20, who had a low FT4 due to primary hypothyroidism (Table 1). No statistically significant differences in these parameters were found between $\mathrm{mt} / \mathrm{mt}$, wt/mt and $\mathrm{wt} / \mathrm{wt}$ groups.

After 1 year of treatment with human recombinant $\mathrm{GH}, \quad 0.1 \mathrm{U} / \mathrm{kg} /$ day s.c., subjects nos 1 and 3 (prepubertal during this period) grew $14 \mathrm{~cm}$ and $12 \mathrm{~cm}$ respectively, without showing a significant decrease of growth velocity during the treatment period.

The height of subjects who were heterozygous (wt/ $\mathrm{mt}$ ) for the GHRH-R gene mutation did not differ 

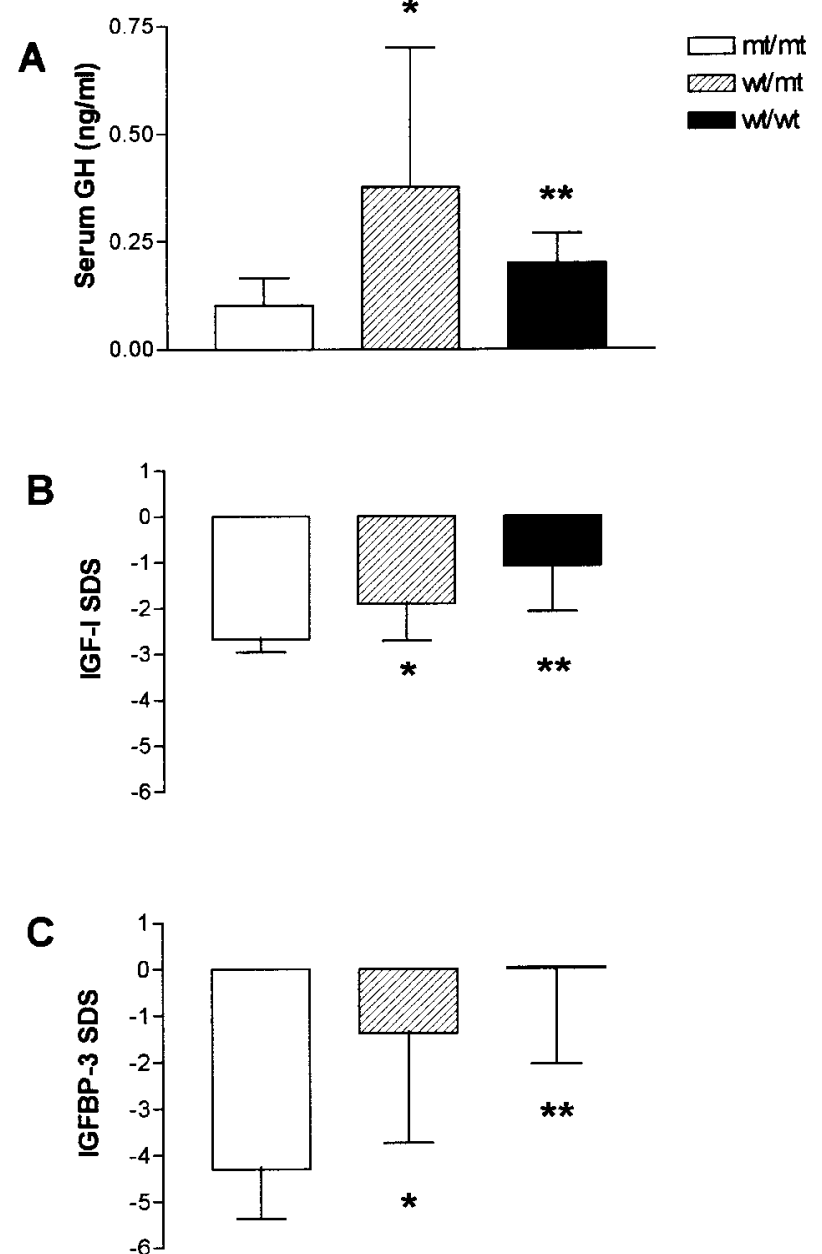

Figure 2 Serum GH (A), IGF-1 SDS (B), and IGFBP-3 SDS (C) in subjects with growth hormone deficiency $(\mathrm{mt} / \mathrm{mt})(n=18$, except for IGF-I SDS with $n=17$ ), subjects heterozygous for GHRH-R mutation (wt/mt) $(n=13)$ and subjects homozygous for the wild type allele (wt/wt) $(n=5)$. $P$ values (all relative to $\mathrm{mt} / \mathrm{mt}$ ) are: ${ }^{*} P=0.0004,{ }^{* \star} P=0.009$, in $(\mathrm{A}),{ }^{*} P=0.0003,{ }^{* \star} P=0.001$ in $(\mathrm{B})$, and ${ }^{*} P=0.0001,{ }^{*} P=0.007$ in $(\mathrm{C})$.

significantly from those who were homozygous for the normal type allele (wt/wt), as assessed by SDS for height $(-1.84 \pm 1.44$ SDS, range: -4.45 to 1.29 SDS, vs $-1.85 \pm 0.81$ SDS, range: -2.61 to -1.61 SDS, $\left.Z_{T}=0.25, P=0.84\right)($ Table 1). However, serum levels of both IGF-I and IGFBP-3 were lower in the $\mathrm{wt} / \mathrm{mt}$ group compared with the wt/wt group, but these differences did not reach statistical significance $\left(Z_{T}=1.54, P=0.14\right.$ respectively $Z_{T}=1.24, P=0.24$ respectively), and this was also seen for both IGF-I and IGFBP-3 expressed as SDS $Z_{T}=1.63, P=0.11$, and $Z_{T}=0.94, P=0.37$ respectively) (Fig. $2 \mathrm{~B}$ and $\mathrm{C}$ ).

A statistically significant inverse correlation between serum IGF-I and age was found for the heterozygous $(\mathrm{wt} / \mathrm{mt})$ group $\left(r_{s}=-0.79, \quad P=0.001\right.$ for IGF-I expressed as ng $/ \mathrm{ml}$, and $r_{s}=-0.73, P=0.005$ for

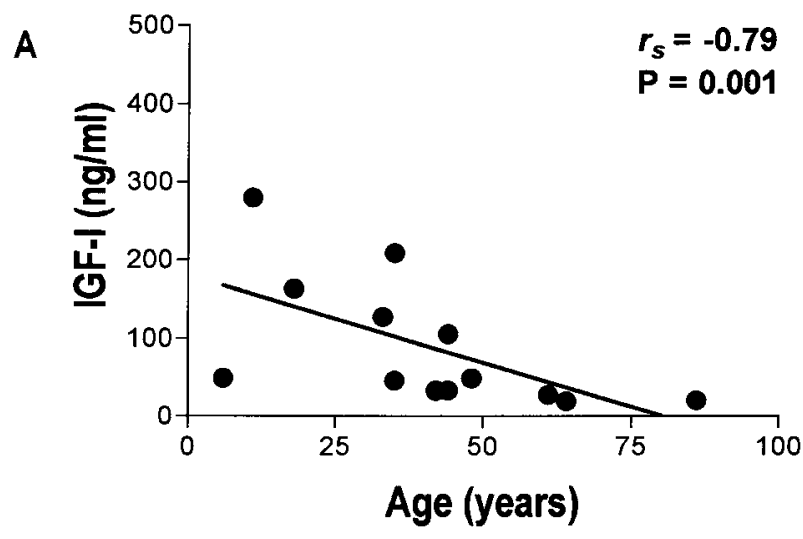

B

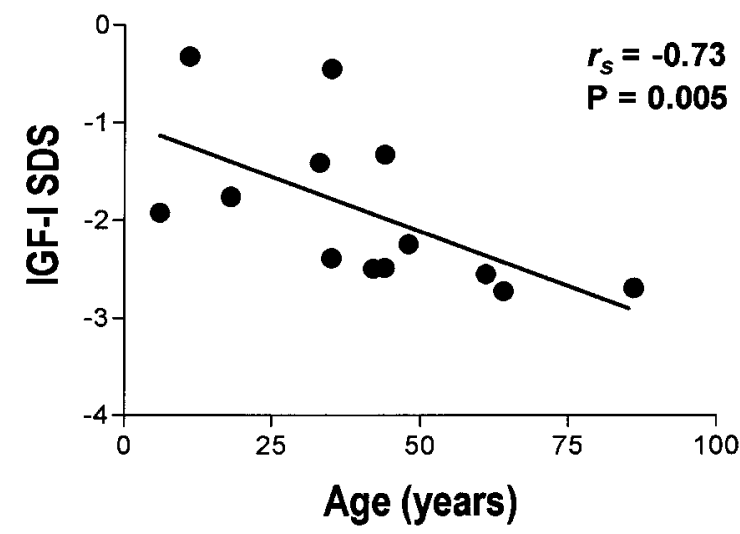

Figure 3 Correlation (Spearman rank order test) between serum IGF-I expressed as $\mathrm{ng} / \mathrm{ml}(\mathrm{A})$ and as SDS (B) and age of hetero-zygote cases for GHRH-R mutation (wt/mt).

IGF-I SDS) (Fig. 3), but not for the small wt/wt group $\left(r_{s}=-0.90, P=0.08\right.$ for IGF-I expressed as $\mathrm{ng} / \mathrm{ml}$, and $r_{s}=0.00, P=1.05$ for IGF-I SDS). The IGF-I/IGFBP-3 ratio did not differ between the wt/mt $(48.15 \pm 49.48$, range: 7 to 171$)$ and the $w t / w t(49.00 \pm 27.42$, range: 15 to 88$)$ groups $(P>0.1)$. No statistically significant correlation was found between the IGF-I/IGFBP-3 ratio and height SDS or age.

\section{Discussion}

GHD is an uncommon condition, ocurring with a frequency of 1:4000 to 1:10000 (7). Familial GHD accounts for only 3 to $30 \%$ of GHD (8). Two types of autosomal recessive FGHD involving mutations in the gene for GH have been described (8): (i) FGHD IA is due to deletions in the GH gene leading to absence of GH, with severe dwarfism and frequent development of antiGH antibodies when exogenous GH therapy is administered; (ii) FGHD IB is due to GH deficiency caused by mutations in the GH gene that lead to defective GH. A clinically indistinguishable picture is caused by a mutation in the GHRH receptor, as recently described in 3 kindreds from the Indian subcontinent (11) and in 
the patients we studied (1). FGHD II is transmitted via an autosomal dominant mode of inheritance, due to dominant-negative mutations, and FGHD III is a rare syndrome with $\mathrm{X}$-linked inheritance.

Random serum GH is of limited diagnostic value for GHD. However, GH deficiency was so severe in our cases that basal serum levels of GH, IGF-I and IGFBP-3 were sufficiently low to diagnose GHD. Furthermore, GH stimulation tests (clonidine, insulin induced hypoglycaemia and GHRH) confirmed GHD in other affected individuals from the same genealogy (1). IGF-I in the $\mathrm{mt} / \mathrm{mt}$ GHD group was distinctly lower than $\mathrm{wt} / \mathrm{mt}$ and wt/wt non-GHD groups, except for the subjects older than 60 years of age (all three wt/mt), who have low serum IGF-I concentrations similar to the $\mathrm{mt} / \mathrm{mt}$ subjects (Table 1). IGFBP-3 concentrations also declined with age but less dramatically than IGF-I. Lower serum IGF-I levels with advancing age is not unexpected (12). It is interesting that very low serum IGF-I and IGFBP-3 levels were found in the taller $(1.70 \mathrm{~m})$ and older $(86$ years of age) wt/mt subject here studied (no. 34). Random serum GH did not clearly separate $\mathrm{mt} / \mathrm{mt}$, wt/ $\mathrm{mt}$, and wt/wt subjects, but it helped to exclude $\mathrm{GH}$ resistance $(13,14)$.

Undernutrition, a condition not infrequent in the Itabaianinha region, could contribute, together with $\mathrm{GH}$ deficiency, to the extreme short stature of many of the $\mathrm{GH}$ deficient individuals. In support of this hypothesis, mean heights for both wt/mt and wt/wt subjects were also low (mean \pm S.D. of height SDS: $-1.84 \pm 1.44$ and $-1.85 \pm 0.81$ respectively), with one very short $\mathrm{wt} / \mathrm{mt}$ female individual, no. 30 , with -4.45 SDS for height, in this group. Low serum IGF-I in $9 \mathrm{wt} / \mathrm{mt}$ subjects (nos $22,24,27,28,29,31,32,33$, and 34) and in $1 \mathrm{wt} / \mathrm{wt}$ subject (no. 39) control relatives, as well as low serum IGFBP-3 in 5 of the wt/mt group, could also be related to their nutritional status. However, the normal or even increased weight for height, as indicated by BMI percentiles for height age in all 10 affected individuals in which this parameter was determined, indicates that severe undernutrition is unlikely in this group.

Heterozygous (wt/mt) carriers of the IVSI $+1 \mathrm{G} \rightarrow \mathrm{A}$ allele were physically similar to their non-carrier (wt/ wt) relatives. However, their serum IGF-I and IGFBP-3 levels were lower (the small number of subjects, particularly in the wt/wt group, is likely to have precluded this achieving statistical significance). It is possible that normal free IGF-I, as indicated by similar IGF-I/IGFBP-3 ratio between these two groups, might have been sufficient to compensate for this lower total IGF-I. IGF-I decreased with age in both $\mathrm{wt} / \mathrm{mt}$ and $\mathrm{wt} / \mathrm{wt}$ groups, the latter being too small to reach statistical significance. The age-related decrease in IGF-I levels was not greater in the heterozygotes as compared with the small group of subjects homozygous for the wild type allele. However, IGF-I was low in 9 of the 13 heterozygotes $(87.5 \%)$, mainly in the older individuals ( 7 out of 9 heterozygotes 35 years or older had low
IGF-I, in contrast to 2 in the 5 younger heterozygous individuals), with very low IGF-I, indistinguishable from the $\mathrm{mt} / \mathrm{mt}$ group. Furthermore, this inverse correlation with age was maintained when IGF-I was expressed as standard deviation scores from the normal mean values in the $\mathrm{wt} / \mathrm{mt}$ group but not in the wt/wt group. These data suggest that there might be a relationship between heterozygous state for GHRH-R mutation and the declining IGF-I with age. Further studies with more $\mathrm{wt} / \mathrm{mt}$ and $\mathrm{wt} / \mathrm{wt}$ subjects are clearly necessary to test for this hypothesis.

Subjects from the Pakistani kindred heterozygous for a GHRH-R mutation were reported to have 'only slight or perhaps no growth retardation' (10). Their height SDS was very similar to the Itabaianinha individuals $(-1.89 \pm 1.1$, compared with $-1.84 \pm 1.44$ respectively). Furthermore, as in our case, their serum IGF-I and IGFBP-3 levels seemed to be lower than normal mean values, as well as their $\mathrm{GH}$ response to GHRH, L-dopa and clonidine.

Affected GHD individuals or heterozygous GHD gene carriers from elsewhere could have arrived in the region and their numbers could have increased due to geographical and socio-economical features favouring consanguineous marriages, especially given the genetic evidence of a founder effect (1). Considering their caucasian features and light-coloured hair and eyes, there is the possibility that their GHD gene had been introduced during the brief (1630 to 1654) Dutch domination of the Brazilian northeast region, particularly during the attack on Sergipe in 1637, when the territory had only one small town and 8 sugar cane plantations and mills. Therefore, if that gene mutation had occurred prior to the establishment of Itabaianinha, it could be present in other areas of the world where the same population has emigrated.

The observation of a possible partial phenotype (reduced serum IGF-I) in heterozygous subjects, without evidence of an effect on stature, may indicate that optimal somatic growth can be achieved with less than maximal activation of the GH-IGF-I axis. It is possible, however, that lower IGF-I serum levels in adult age may cause changes in organs influenced by GH action (such as bone, adipose tissue and lipid metabolism). A closer evaluation of these parameters in subjects heterozygous for the mutation is currently underway in the Itabaianinha kindred.

Only three other genealogies with familial growth hormone deficiency due to a mutation in the GHRH receptor gene have been described (9-11). All three families, from the Indian subcontinent (from Bombain, India (9), Sindh, Pakistan (10), and Delf, Sri Lanka (11)), had the same G-to-T transversion (GAG $\rightarrow$ TAG) in codon 72 (exon 3), corresponding to amino acid residue 50 in the mature GHRH receptor protein, which creates a stop codon and predicts a truncated protein at its extracellular domain. Growth hormone deficiency in the Itabaianinha genealogy is due to a different GHRH 
receptor mutation, a G-to-A transition of the first base of the $5^{\prime}$ splice site at the beginning of intron 1 (IVSI+1G $\rightarrow A$ ), which predicts a retention of intron sequences in the mature mRNA and utilization of a downstream cryptic splice donor site (1). Since both mutations predict severely truncated GHRH receptor proteins, it is not surprising that clinical findings were also similar in respect to the degree of growth impairment and apparent absence of phenotypic changes attributable to some eventual extra-pituitary action of GHRH.

\section{Acknowledgements}

This study was partially supported by Pharmacia \& Upjohn, São Paulo, Brazil. SPAT and NA are CNPq research investigators (300346182-4). R S was supported in part by a grant from the Genentech Foundation for Growth and Development. The authors wish to thank Dr Maria Tereza Ivanoff, Ms Maria da Graça Cavalcanti and Ms Sara Maria Santos for helping in data collection, Ms Ana Mercedes de Sousa Cavaleiro for laboratory expertise and Pharmacia \& Upjohn for support and kind donation of recombinant human GH and the application device (Genotropin and Kabipen).

\section{References}

1 Salvatori R, Hayashida CY, Aguiar-Oliveira MH, Phillips III JA, Souza AHO, Gondo RG, Toledo SPA, Conceição MM, Prince M, Maheshwari HG, Baumann G \& Levine MA. Familial dwarfism due to a mutation of the growth hormone-releasing hormone receptor gene. Journal of Clinical Endocrinology and Metabolism 199984 917-923.

2 WHO Working Group. Use and interpretation of anthropometric indicators of nutritional status. Bulletin of the World Health Organization 198664 929-941.

3 Hammer LD, Kraemer HC, Wilson DM, Ritter PL \& Dornbusch SM Standardized percentile curves of body-mass index for children and adolescents. American Journal of Diseases of Children 1991145 259-263.

4 Vimpani GV, Vimpani AF, Lidgard GP, Cameron EHD \& Farquhar JW. Prevalence of severe growth hormone deficiency. British Medical Journal 19772 427-430.

5 Rona RJ \& Tanner JM. Aetiology of idiopathic growth hormone deficiency in England and Wales. Archives of Disease in Childhood 197752 197-208.

6 Lacey KA \& Parkin JM. Causes of short stature: a community study of children in Newcastle upon Tyne. Lancet 1974 1 42-45.

7 Lindsay R, Harris D, Feldkamp M, Robertson J \& Rallison M. Utah growth study: growth hormone deficiency prevalence. Pediatric Research 199333 81A (Abstract).

8 Phillips III JA \& Cogan JD. Molecular basis of familial human growth hormone deficiency. Journal of Clinical Endocrinology and Metabolism 199478 11-16.

9 Wajnrajch MP, Gertner JM, Harbison MD, Chua Jr SC \& Leibel RL. Nonsense mutation in the human growth hormone-releasing hormone receptor causes growth failure analogous to the little (lit) mouse. Nature Genetics 199612 88-90.

10 Maheshwari HG, Silverman BL, Dupuis J \& Baumann G. Phenotype and genetic analysis of a syndrome caused by an inactivating mutation in the growth hormone-releasing hormone receptor: dwarfism of Sindh. Journal of Clinical Endocrinology and Metabolism 199883 4065-4074.

11 Netchine I, Talon P, Dastot F, Vitaux F, Goossens M \& Amselem S. Extensive phenotypic analysis of a family with growth hormone (GH) deficiency caused by a mutation in the GH-releasing hormone receptor gene. Journal of Clinical Endocrinology and Metabolism $199883432-436$.

12 Rosenfeld RG, Wilson DM, Lee PDK \& Hintz RL. Insulin-like growth factors-I and -II in evaluation of growth retardation. Journal of Pediatrics 1986109 428-433.

13 Berg MA, Argente J, Chernausek S, Gracia R, Guevara-Aguirre J, Hopp M, Pérez-Jurado L, Rosenbloom A, Toledo SPA \& Francke U. Mutation spectrum in growth hormone insensitivity syndrome. American Journal of Human Genetics 199352 998-1005.

14 Saldanha PH \& Toledo SPA. Familial dwarfism with high IR-GH: report of two affected sibs with genetical and epidemiological considerations. Human Genetics 198159 367-372.

Received 27 October 1999

Accepted 3 February 2000 